\title{
Compensatory rebound of body movements during sleep, after asphyxia in neonatal rats $^{1}$
}

\section{Resposta compensatória dos movimentos corporais do sono após a asfixia em ratos recém- nascidos}

\author{
Olivia Adayr Xavier Suarez ${ }^{I}$, Katsumasa HoshinoII \\ ${ }^{\text {I }}$ Master, Paediatrics Post-Graduate Program of the Botucatu Medical School, UNESP, Brazil. \\ ${ }^{\text {II }}$ Full Professor, Department of Biological Sciences of Bauru Sciences School, UNESP, Brazil.
}

\begin{abstract}
Purpose: The usefulness of body movements that occur during sleep when assessing perinatal asphyxia and predicting its longterm consequences is contradictory. This study investigated whether neonatal rats manifest these movements in compensatory rebound after asphyxia, and if these alterations play an important role in its pathogenesis. Methods: Eight neonatal rats (aged 648h) were implanted with small EMG and EKG electrodes and sleep movements were recorded over a 30-minute control period. Recordings were continued during asphyxia caused by the enclosure of the animal in a polyvinyl sheet for 60 minutes, followed by a 30-minute recovery period. Results: Heart rate was lowered to bradycardic level during asphyxia causing behavioral agitation and increased waking time during the initial phase (30 minutes). Sleep-related movements were also significantly reduced from $12.5 \pm 0.5$ (median $\pm \mathrm{SE} / 2 \mathrm{~min}$ ) to $9.0 \pm 0.44$ in the final half of the period (Anova, $\mathrm{p}<0.05$ ). Movement frequency increased in the recovery period to $15.0 \pm 0.49$ (Anova, $\mathrm{p}<0.05$ ). Conclusion: These data show that newborn rats present compensatory rebound of body movements during sleep which may help in the diagnosis of asphyxia and other problems related to sleep parameters.
\end{abstract}

Key words: Sleep. Infant, Newborn. Asphyxia. Motor Activity. Rats.

\section{RESUMO}

Objetivo: A utilidade dos movimentos corporais (MC) que ocorrem durante o sono para diagnosticar e predizer as conseqüências, em longo prazo, da asfixia perinatal é contraditório. Este estudo investigou se ratos recém-nascidos (RN) manifestam MC em resposta compensatória à asfixia, e se estas alterações podem ter alguma importância na sua patogênese. Métodos: Oito ratos RN (6-48h de vida) foram submetidos à implantação de pequenos eletrodos para registros da eletromiografia e eletrocardiografia. Os $\mathrm{MC}$ e a freqüência cardíaca $(\mathrm{FC})$ foram registrados durante períodos de 30 min: fase controle $\left(\mathrm{F}_{1}\right)$, fases de asfixia $\left(\mathrm{F}_{2} ; \mathrm{F}_{3}\right)$ e fase de recuperação pós-asfixia $\left(\mathrm{F}_{4}\right)$. A asfixia foi promovida pelo envolvimento completo do animal com uma lâmina de polivinil. Resultados: A FC diminuiu progressivamente durante $\mathrm{F}_{2}$ e $\mathrm{F}_{3}$ até a bradicardia. Em $\mathrm{F}_{2}$ houve grande agitação dos animais e aumento dos períodos de vigília. Em $\mathrm{F}_{3}$ houve redução significante dos $\mathrm{MC}$ de $12,5 \pm 0,5(\mathrm{Md} \pm \mathrm{SE} / 2 \mathrm{~min})$ para 9,0 $\pm 0,44$ $(\mathrm{P}<0,05)$. A freqüência dos $\mathrm{MC}$ aumentou em $\mathrm{F}_{4}$ para $15,0 \pm 0,49$. Conclusão: Estes dados mostram que ratos $\mathrm{RN}$ com asfixia apresentam MC compensatórios durante o sono que podem ajudar no diagnóstico desta afecção e de outros problemas relacionados aos parâmetros do sono.

Descritores: Sono. Recém-Nascido. Asfixia. Atividade Motora. Ratos.

1. Research performed at the Experimental Laboratory, Botucatu College of Veterinary Medicine and Animal Science, State University of São Paulo (UNESP), Brazil.

\section{Introduction}

Perinatal asphyxia (PA) is one of the most important causes of brain injury and neurological sequelae during the neonatal period, and it is associated with high rates of mortality and morbidity ${ }^{1}$. The incidence of PA is about $1.0-1.5 \%$ in most centers and is usually related to gestational age and birth weight ${ }^{2}$. It occurs in $9.0 \%$ of infants born before 36 weeks of gestation and in $0.5 \%$ of older infants. PA may develop in antepartum $(20 \%)$, intrapartum $(30 \%)$, intrapartum and antepartum (35\%), or postpartum $(10 \%)$ periods $^{3}$. Despite the magnitude of the problem, there is no sufficiently sensitive method for early PA diagnosis or the prognosis of its complications. Electronic fetal monitoring of heart rate patterns in labor or the traditional signs of fetal distress have not proved to predict long-term neurological outcome ${ }^{4}$. The same has been observed by meconial fluid 
analysis, Apgar scores, excess $\mathrm{pH}$ and base measurements, and other specific markers of systemic lesions, many of which are still only available in experimental or clinical research centers ${ }^{5-}$ ${ }^{10}$. There are also limitations with later indicators of brain injury, such as electroencephalography (EEG), polysomnography, evoked potential, blood flow studies, and neuroimaging, because not all these techniques are widely available, and it is not clear how specific they are for PA or to what extent they reflect primary as opposed to downstream pathology ${ }^{11}$. All these facts indicate the importance of looking for easy noninvasive methods that allow early assessment of PA and its future consequences.

Methods of assessing PA using brain electrical activity recordings seem appropriate as newborns sleep most of the time $^{12}$. EEG recordings, complemented by eye, limb, and other body movements, reveal three distinct sleep states in human newborns - active sleep, quiet sleep, and intermediate sleep. Changes in the ontogenetic characteristics of these states have been recommended when evaluating PA induced neurological insult $^{13,14}$, and sleep-cycle consolidation latencies after PA has shown good correlation with prognostics ${ }^{15}$. PA was shown to reduce active sleep, and increase quiet and intermediate sleep ${ }^{16}$.

Eye, limb, and other body movements during sleep are so conspicuous that their potential as PA markers has also been investigated. Hypoxia, an important condition determined by asphyxia, reduces the frequency and rate of fetal movements; hypoxia is also indicative of the development subsequent $\mathrm{SNC}^{17}$. Different types of body movements have been classified and counted in normal newborns ${ }^{18}$, and changes in their emission in newborns with neurological problems, including PA, are alleged to predict future brain dysfunction ${ }^{19,20}$. Changes in sleep and related body movements induced by severe neonatal hypoxia are maintained throughout adult life ${ }^{21}$. However contradictory results were also found. EEG patterns of neonates who suffered asphyxia were similar to those showing normal development $^{22}$, and quantitative changes in motor manifestations during sleep were considered inadequate to differentiate between healthy and neurologically compromised children ${ }^{23}$.

Asphyxia is life-threatening and incompatible with sleep. Sleep deprivation can therefore result in cases of longer PA. Sleep deprivation is followed by a subsequent period of prolonged sleep, a phenomenon known as compensatory rebound ${ }^{24}$. Sleep reduction and rebound may play an important role in contradictions concerning the use of EEG and sleep motor manifestations in the assessment of PA. Experimental data that may help clarify the problem, including rebound time onset, are not well known. Significant sleep rebound in newborn rats is reported to start by the $3 \mathrm{rd} \mathrm{week}^{25}$, but stress-induced sleep rebound onset seems to occur earlier ${ }^{26}$.

This study reports significant manifestation of sleep motor rebound in 1-2 day old rats, previously submitted to a period of asphyxia.

\section{Methods}

Eight newborn Wistar rats between 6 and 48 hours old from the São Paulo State University Central Animal Breeding
Center, were used without determining gender. After recovery from manipulation caused by the placement of electromyographic (EMG) and electrocardiographic (EKG) electrodes on the animals' skin continuous recordings were made throughout the control period $\left(\mathrm{P}_{1}\right)$ of 30 minutes, 60 minutes of asphyxia (divided into an initial 30 minutes $\left(\mathrm{P}_{2}\right)$ and final 30 minutes $\left(\mathrm{P}_{3}\right)$ period), and 30 minutes recovery $\left(\mathrm{P}_{4}\right)$. All experimental procedures had been formally submitted to and approved by the Faculty's Research Ethics Committee.

Seven $2 \mathrm{~mm}$ long steel fish-hooks fixed by adhesive tape to the skin surface of the neonatal rat, served as EMG and EKG electrodes. They were positioned on the right and left cervical and deltoid regions, and on the anterior and posterior sides of the chest (bipolar derivations). One electrode was placed on the lateral part of the right thigh and used concomitantly to the ground electrode (Figure 1). EMG and EKG recordings were made using an 8 channel polygraph (Eletromedicina Berger Ind. Com. Ltda., São Paulo, SP, Brazil), with a high-frequency filter set at $50 \mathrm{~Hz}$, and amplitude adjusted to the different recording conditions of each animal, and chart velocity of $10 \mathrm{~mm} / \mathrm{s}$. Recordings were made without anesthesia or sedation, with the animal maintained on a quilt to minimize heat loss. All observations were made between 1 and 5h PM.
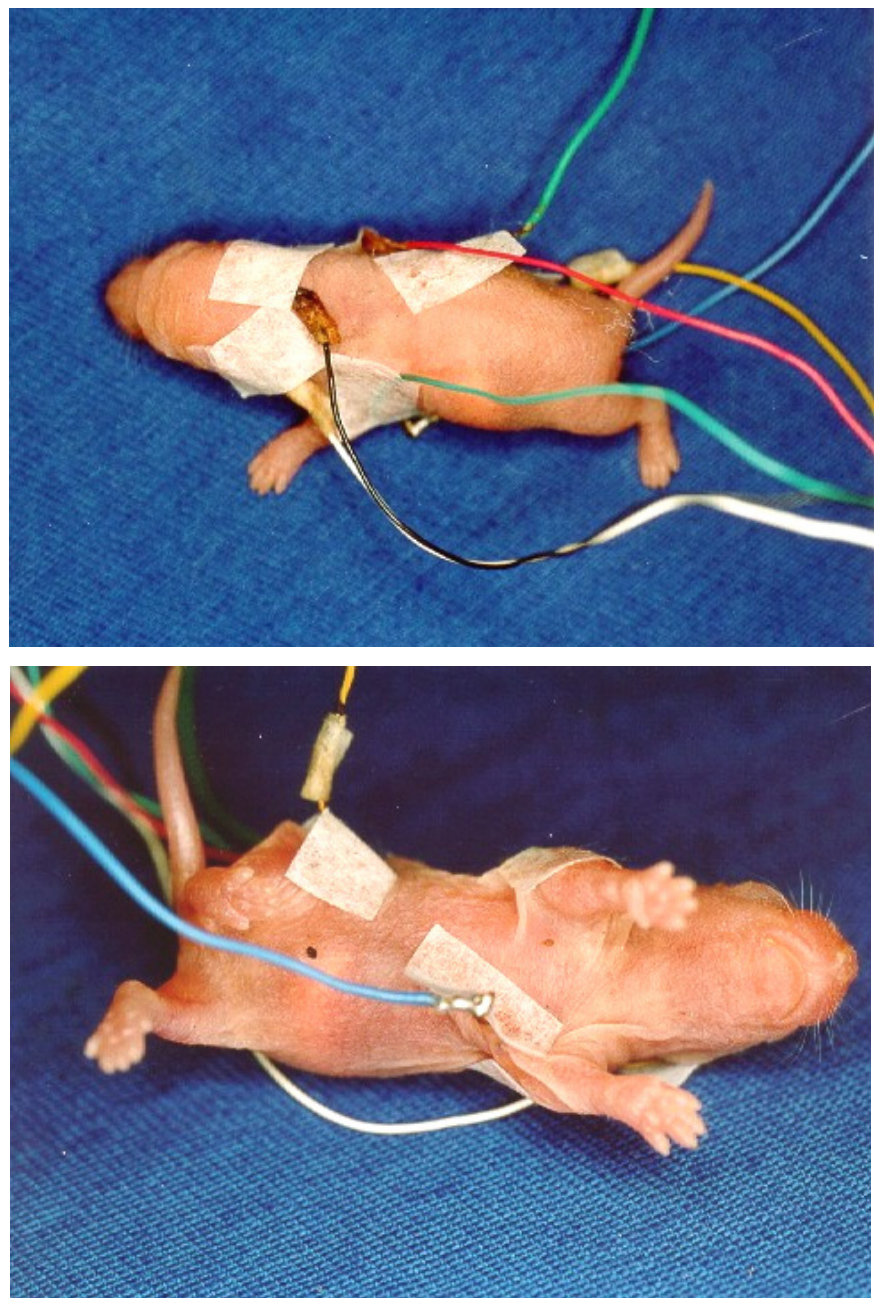

FIGURE 1 - Long steel fish-hooks used as electrodes positioned for EMG and EKG recordings in neonatal rats 
Animals breathed atmospheric air during the control $\left(\mathrm{P}_{1}\right)$ and recovery periods $\left(\mathrm{P}_{4}\right)$. Asphyxia was imposed by covering the entire body of the rat with a polyvinyl sheet, providing complete adhesion to the animal's body. Asphyxia was terminated by puncturing the polyvinyl sheet and exposing the animal's head to atmospheric air.

Motor activity, skin color, and behavioral sleep-wake rhythm were monitored and data recorded on the EMG chart. Time spent awake (seconds) and asleep (seconds), the numbers of sleep-wake cycles, sleeping body movements, and heart rate were computed from the recordings after the end of observation periods. Awake periods were defined by the presence of high electromyographic activity corresponding to background tonus and deflection movements. Sleep was determined by the isoelectric recordings of muscular atonia interspersed with pha-

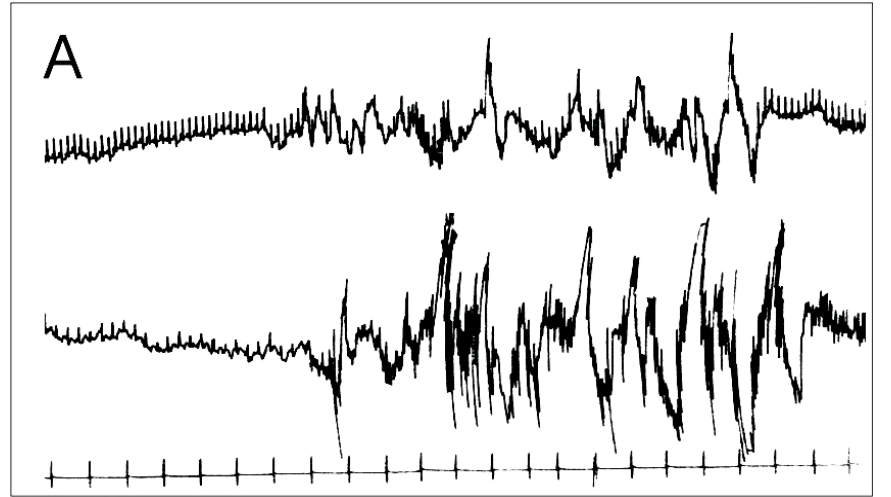

sic and short-lasting tonic movements (Figure 2). Sleep movements were quantified by adding the number of phasic deflections and the number of consecutive 0.5 -second intervals showing tonic muscular contractions. Concomitant movements recorded on different EMG channels were counted only once and the longer tonic movements considered for quantification. The counted movements were expressed as number per 2 minutes, and median values plus standard error determined for each 30 minute period of the experiment. The number of sleeping movements, determined by two independent observers with $96 \%$ concordance, and discrepant cases were discussed and recounted until consensus.

Analysis of Variance, complemented by the Dunn test, was used to test significant difference at a level of 0.05 .

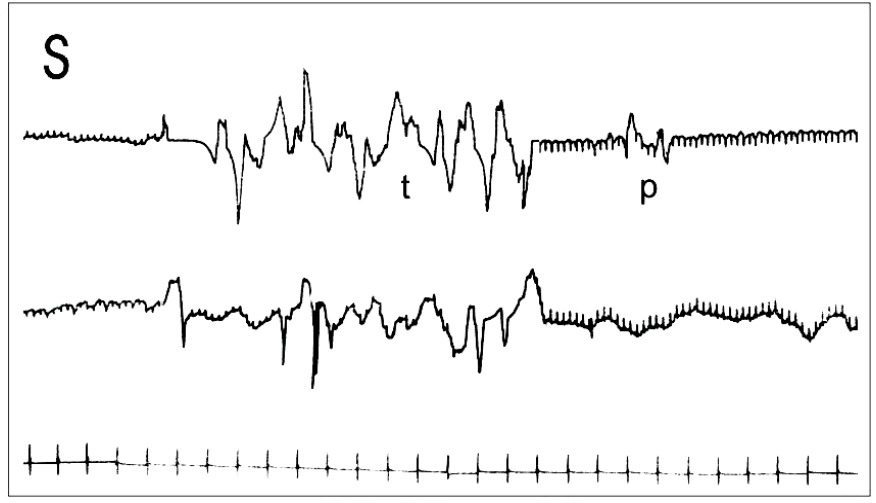

FIGURE 2 - Electromyographic and electrocardiographic recordings in neonatal rats. A: waking period with gross body movement; S: sleep period with atonia and phasic (p) and tonic (t) movements. Cal. $1 \mathrm{sec}-50$ microV

\section{Results}

Neonatal rats remained quiet, sleeping most of the time, with short duration waking episodes in the control period. Initially, asphyxia induced long duration vigorous movements, with agitation in the distal extremities, mouth movements, and vocalization. Behavioral agitations progressively decreased until rats were hypoactive and longer sleep periods detected. Sleep was prevalent in the recovery period, when frequent strong phasic muscle movements sometimes woke the animal. Cyanosis was not observed during the asphyxia period, although a slight change in skin color from clear to dark pink was noted. It reversed after 10 minutes in the recovery period.
Table 1 depicts sleep parameter results in newborn rats. As shown, asphyxia initially induced a transient period of increased duration waking episodes during $\mathrm{P}_{2}$ significantly reducing the amount of sleep. Sleep-related body movements were reduced throughout the entire asphyxia period $\left(\mathrm{P}_{2}\right.$ e $\left.\mathrm{P}_{3}\right)$, with a significant increase during the subsequent recovery period $\left(\mathrm{P}_{4}\right)$. Behavioral inspection indicated that these rebound movements were more intense than those observed in other experimental periods.

EKG data indicated that significant bradycardia was prevalent throughout the asphyxia period.

TABLE 1 - Sleep parameter results in newborn rats. Median \pm SE values for 8 rats (6-48h old) during a 30min control period $\left(\mathrm{P}_{1}\right)$; a first $30 \mathrm{~min}\left(\mathrm{P}_{2}\right)$ and second $30 \mathrm{~min}\left(\mathrm{P}_{3}\right)$ period of asphyxia; and a recovery $30 \min$ period $\left(\mathrm{P}_{4}\right)$. $\mathrm{s}=$ seconds, $\mathrm{n}=$ number, $\min =$ minutes

\begin{tabular}{|c|c|c|c|c|}
\hline \multirow{3}{*}{$\begin{array}{l}\text { VARIABLES } \\
\text { Waking episode duration (s) }\end{array}$} & \multicolumn{4}{|c|}{ EXPERIMENTAL PERIOD } \\
\hline & Control $\left(\mathbf{P}_{1}\right)$ & Asphyxia $\left(\mathbf{P}_{2}\right)$ & Asphyxia $\left(\mathbf{P}_{3}\right)$ & Recovery $\left(\mathbf{P}_{4}\right)$ \\
\hline & $19.0 \pm 2.58$ & $41.0 \pm 3.20^{* *}$ & $28.0 \pm 4.39$ & $22.0 \pm 6.14$ \\
\hline Sleep episode duration (s) & $175.5 \pm 28.83$ & $64.0 \pm 13.32^{*}$ & $137.5 \pm 45.88$ & $125.0 \pm 84.64$ \\
\hline Sleep-waking cycles (n) & $7.0 \pm 0.72$ & $11.0 \pm 1.54^{* *}$ & $4.5 \pm$ & $5.0 \pm$ \\
\hline Sleep movements ( $\mathrm{n} / 2 \mathrm{~min})$ & $12.5 \pm 0.50$ & $11.0 \pm 0.62^{*}$ & $9.0 \pm 0.44^{*}$ & $15.0 \pm 0.49^{* *}$ \\
\hline Heart rate (beats/min) & $303.0 \pm 12.94$ & $222.0 \pm 11.21^{*}$ & $202.0 \pm 10.63^{*}$ & $252.0 \pm 13.06$ \\
\hline
\end{tabular}

\footnotetext{
* significantly lower than control; ** significantly higher than control (Anova, $\mathrm{p}<0.05)$;
} 


\section{Discussion}

Firstly one must consider that EEG recording in neonatal rats is technically difficult as their skulls are not sufficiently developed for conventional electrodes to beattached. The absence of this recording in our study does not seem to affect the conclusion. Sleep in neonatal rats appears to be composed almost entirely of active sleep ${ }^{27}$, which permits us to consider it in the context of other literature data obtained in EEG monitored sleep. It is also technically impossible to record all bodily movements in neonates. This does not however invalidate rebound detection as frequencies were determined in the same animals during a control period.

The method used to promote asphyxia in this study was based on a previous study using a plastic bag to obtain this experimental condition ${ }^{28}$ and it seemed reliable because it reproduces bradycardia as reported in literature ${ }^{29}$ which induces an initial increase in waking ${ }^{30}$. The recovery of neonatal rats after 60 minutes of asphyxia cannot be attributed to methodological inadequacy because their high resistance is well documented $^{31}$.

The significant increase in sleep-related body movement frequency after asphyxia in 6-48h old rats indicates that compensatory rebound is manifested perinatally. This rebound has been reported in adult experimental animals such as dogs submitted to obstructive apnea ${ }^{32}$, and has also been observed in some human neonates affected by complications ${ }^{19,33}$. These data, together with the observation that sleep movements decrease during asphyxia, indicate that it is important to consider this process in studies assessing the value of these motor manifestations in diagnosis and prognosis. This not only appears to be true for asphyxia, but also for all other sleep manifestation based neurological evaluations.

Active sleep is observed in fetal life $\mathrm{e}^{17}$. This sleep state is manifested by preterm babies ${ }^{34}$ with higher motor movement frequency than full term babies. Similarly, newborns from undernourished mothers show reduced active sleep, whereas motor movements reveal high densities. These and other similar compensation indicating data suggest that rebound restores the delay (or amount) of programmed active sleep, in order to synchronize different processes necessary for the healthy development and maintenance of the nervous system. We may therefore consider rebound as a marker of neural recovery and normal development, whereas its absence may be indicative of negative neurological outcome.

\section{Conclusion}

Newborn rats present compensatory rebound of body movements in sleep which may help in the diagnosis of asphyxia and other problems related to sleep parameters.

\section{References}

1. de Dios G, Moya M, Vioque J. Risk factors predictive of neurological sequelae in term newborn infants with perinatal asphyxia. Rev Neurol. 2001;32 (7):210-6.
2. Wayenberg JL, Vermeylen D, Damis E. Definition of asphyxia and incidence of neurological and systemic complication in the full-term newborn. Arch Pediatr. 1998;5(10):1065-71.

3. Legido A, Katsetos CD, Mishra OP, Dellivoria-Papadopoulos M. Perinatal hypoxic ischemic encephalopathy: current and future treatments. Int Pediatr. 2000;15:143-51.

4. Freeman R. Intrapartum fetal monitoring: a disappointing story. N Eng J Med. 1990;322:624-6.

5. Carter BS, Haverkamp AD, Merenstein GB. The definition of acute perinatal asphyxia. Clin Perinatol. 1993;20(2):287-304. 6. Marrin M, Paes BA. Birth asphyxia: does the Apgar score have diagnostic value? Obstet Gynecol. 1988;72:120-3.

7. Gilstrap LC III, Leveno KJ, Burris J, Williams ML, Little BB. Diagnosis of birth asphyxia on the basis of fetal $\mathrm{pH}$, Apgar score, and newborn cerebral dysfunction. Am J Obstet Gynecol. 1989;161(3):825-30.

8. Fee SC, Malee K, Deddish R, Minogue JP, Socol ML. Severe acidosis and subsequent neurological status. Am J Obstet Gynecol. 1990;162:802-6.

9. Fernandez F, Verdu A, Quero J, Ferreiros MC, Daimiel E, Roche MC, Lopez-Martin V. Cerebrospinal fluid lactate levels in term infants with perinatal hypoxia. Pediatr Neurol. 1986;2:39-42.

10. Saugstad OD. Hypoxanthine as an indicator of hypoxia: Is role in health and disease through free radical production. Pediatr Res. 1988;23:143-50.

11. Nelson KB, Emery III S. Birth asphyxia and the neonatal brain: what do we know and when do we know it? Clin Perinatol. 1993; 20(2):327-44.

12. Pillai M, James D. Are the behavioural states of the newborn comparable to those of the fetus? Early Hum Dev. 1990;22(1):39-49.

13. Azzopardi D, Guarino I, Brayshaw C, Cowan F, Price-Williams D, Edwards AD, Acolet D. Prediction of neurological outcome after birth asphyxia from early continuous two-channel electroencephalography. Early Hum Dev. 1999;55(2):11323.

14. Holmes GL, Lombroso CT. Prognostic value of background patterns in the neonatal EEG. J Clin Neurophysiol. 1993;10(3):323-52.

15. Osredkar D, Toet MC, van Rooij LG, van Huffelen AC, Groenendaal F, de Vries LS. Sleep-wake cycling on amplitudeintegrated electroencephalography in term newborns with hypoxic-isquemic encephalopathy. Pediatrics. 2005;115(2):32732.

16. Scher MS, Steppe DA, Beggarly ME, Salerno DG, Banks DL. Neonatal EEG. Sleep disruption mimicking hypoxic-ischemic encephalopathy after intrapartum asphyxia. Sleep Med. 2002;3(5):411-5.

17. Liedtke B. Intrauterine fetal movements and their significance for the condition of the fetus. Z Geburtshilfe Perinatol. 1982;186(5):219-29.

18. Hakamada S, Watanabe K, Hara K, Miyazaki S, Kumagai T. Body movements during sleep in full-term newborn infants. Brain Dev. 1982;4(1):51-5.

19. Hakamada S, Watanabe K, Hara K, Miyazaki S. Hydranendephaly: sleep and movement characteristics. Brain Dev. 1982;4(1):45-9. 
20. Watanabe K, Miyazaki S, Hara K, Hakamada S. Behavioral state cycles, background EEGs, and prognosis of newborns with perinatal hypoxia. Eletroencephalogr Clin Neurophysiol. 1980;49:618-25.

21. Antier D, Zhang BL, Mailliet F, Akoka S, Pourcelot, Sannajust F. Effects of neonatal focal cerebral hypoxia-ischemia on sleep-waking pattern, EcoG power spectra and locomotor activity in the adult rat. Brain Res. 1998;807(1-2):29-37.

22. Koterazawa K, Kodama S, Nakamura H. A power spectral analysis of the EEG in the newborns. II. The power spectral changes of the infants with neonatal asphyxia. No To Hattatsu. 1990;22(6):582-8.

23. Erkinjuntti M. Body movements during sleep in healthy and neurologically damaged infants. Early Hum Dev. 1988;16(23):283-92.

24. Morden B, Mitchell G, Dement W. Selective REM sleep deprivation and compensation phenomena in the rat. Brain Res. 1967;5(3):339-49.

25. Feng P, Ma Y, Vogel GW. Ontogeny of REM rebound in postnatal rats. Sleep. 2001;24(6):645-53.

26. Tiba PA, Tufik S, Suchecki D. Effects of maternal separation on baseline sleep and cold stress-induced sleep rebound in adult Wistar rats. Sleep. 2004;27(6):1146-53.

27. Silva AL. Ritmo de atividade-repouso em animais: aspectos da ontogenia dos movimentos oculares rápidos do sono no rato [Tese de Doutorado]. Universidade Estadual Paulista, Faculdade de Medicina de Botucatu; 1998.

28. Cohen HE, Sacks EJ, Heymann MA, Rudolph AM. Cardiovascular responses to hypoxemia and acidemia in fetal lambs. Am J Obstet Gynecol. 1974;120:817-24.
29. Bakehe M, Miramand JL, Chambille B, Gaultier C, Escourrou P. Cardiovascular changes during acute episodic repetitive hypoxic and hypercapnic breathing in rats. Eur Resp J. 1995;8:1675-80.

30. Pappenheimer JR. Measurement of respiratory exchange and duration of slow-wave sleep in unanaesthetized rats breathing gas mixtures. J Physiol. 1976;260:7-9.

31. Romijn HJ, Hofman MA, Gramsbergen A. At what age on the developing cerebral cortex of the rat comparable to that of the full-term newborn human body? Early Hum Dev. 1991;26:61-7.

32. Horner RL, Brooks D, Kozar LF, Leung E, Hamrahi H, Render-Teixeira CL, Makino H, Kimoff RJ, Phillipson EA. Sleep architecture in a canine model of obstructive sleep apnea. Sleep. 1998;21(8):847-58.

33. Padula NAMR. Estudo vídeo-polissonográfico em recémnascidos de termo pequenos para a idade gestacional e em recémnascidos de termo com intercorrências perinatais leves [Tese de Doutorado]. Universidade Estadual de Campinas, Faculdade de Medicina; 1999.

34. Peirano P, Curzi-Dascalova G, Korn G. Influence of sleep state and age on body motility in normal premature and fullterm neonates. Neuropediatrics. 1986;17:186-90.

\section{Acknowledgement}

The authors are indebted to Prof. Dr. Mitiko Sakate from the College of Veterinary Medicine and Animal Science, UNESP, for her valuable help in this investigation.

\section{Correspondence:}

Conflict of interest: none

Olivia Adayr Xavier Suarez

Rua Dr. Domingos Minicucci Filho, 479

18607-030 Botucatu - SP Brazil

olivia.suarez@yahoo.com.br

Received: November 20, 2007

Review: January 24, 2008

Accepted: February 20, 2008

\section{How to cite this article}

Suarez OAX, Hoshino K. Compensatory rebound of sleeping bodily movements after asphyxia in neonatal rats. Acta Cir Bras. [serial on the Internet] 2008 May-June;23(3). Available from URL: http://www.scielo.br/acb

\footnotetext{
*Color figure available from www.scielo.br/acb
} 